Article

\title{
Prevalence of Multidrug-Resistant Foodborne Pathogens and Indicator Bacteria from Edible Offal and Muscle Meats in Nashville, Tennessee
}

\author{
Siqin Liu ${ }^{1}$, Agnes Kilonzo-Nthenge ${ }^{2, *}$, Samuel N. Nahashon ${ }^{1}$, Bharat Pokharel ${ }^{1}{ }^{\circledR}$, \\ Abdullah Ibn Mafiz ${ }^{1}$ and Maureen Nzomo ${ }^{1}$ \\ 1 Department of Agriculture and Environmental Sciences, Tennessee State University, \\ 3500 John A. Merritt Boulevard, Nashville, TN 37209, USA; sliu@tnstate.edu (S.L.); \\ snahashon@tnstate.edu (S.N.N.); bpokhare@TNState.edu (B.P.); amafiz@tnstate.edu (A.I.M.); \\ mnzomo@tnstate.edu (M.N.) \\ 2 Department of Human Sciences, Tennessee State University, 3500 John A. Merritt Boulevard, \\ Nashville, TN 37209, USA \\ * Correspondence: akilonzontheng@tnstate.edu; Tel.: +1-(615)-963-5437; Fax: +1-(615)-963-5557
}

Received: 21 July 2020; Accepted: 22 August 2020; Published: 28 August 2020

\begin{abstract}
This study investigated the prevalence of antimicrobial-resistant bacteria in retail edible offal and muscle meats in Nashville, Tennessee. A total of 348 retail meats (160 edible offal and 188 muscle) were analyzed for Salmonella enterica serovar, Campylobacter, Escherichia coli, E. coli O157:H7, and enterococci. Bacteria was identified using biochemical and PCR methods. Salmonella enterica serovar (4.4\% and $4.3 \%)$, Campylobacter (1.9\% and $1.1 \%)$, E. coli $(79.4 \%$ and $89.4 \%)$, and enterococci $(88.1 \%$ and $95.7 \%$ ) was detected in offal and muscle meats, respectively. Chicken liver (9.7\%) was most frequently contaminated with Salmonella enterica serovar, followed by ground chicken (6.9\%) and chicken wings (4.2\%). No Salmonella enterica serovar was detected in beef liver, beef tripe, and ground beef. The prevalence of Campylobacter was $6.9 \%, 2.3 \%$, and $1.4 \%$ in beef liver, ground beef, and ground chicken, respectively. None of the meats were positive for E. coli O157:H7. Resistance of isolates was significantly $(p<0.05)$ highest in erythromycin $(98.3 \% ; 99.1 \%)$, followed by tetracycline $(94 \% ; 98.3 \%)$, vancomycin $(88.8 \% ; 92.2 \%)$ as compared to chloramphenicol (43.1\%; 53.9\%), amoxicillin/clavulanic $(43.5 \% ; 45.7 \%)$, and ciprofloxacin $(45.7 \% ; 55.7 \%)$ in offal and muscle meats, respectively. Imipenem showed the lowest resistance $(0 \% ; 0.9 \%)$. A total of 41 multidrug-resistant patterns were displayed. Edible offal could be a source of antibiotic-resistant bacteria.
\end{abstract}

Keywords: antimicrobial resistance; edible offal; muscle meat

\section{Introduction}

American's food demographics continue to adjust as a result of an expanding U.S. population of immigrants [1]. Immigrants maintain their food traditions in the United States, permitting them to continue with their culture, structure, and identity. Western culture including food selection has been influenced by engaging in cultural festivities and activities of immigrants. There is also a long-standing impact of immigration on American cuisine. Several edible offal including fried chopped liver, giblet gravy, liver mush, and gandinga in the U.S. are good examples of dishes which have emerged and embraced as a result of immigration. Edible offal, as well as muscle meats, are consumed for their nutritional benefits [2]. However, undercooked meats are one of the leading origins of foodborne diseases [3]. Meats are frequently contaminated with zoonotic pathogens all through production, processing, distribution, and retail processing [4]. 
Salmonella enterica serovar, Campylobacter, E. coli O157:H7 among others are the most shared foodborne pathogens of animal origin [5]. Escherichia coli and enterococci are also common in meat products and reflect the microbial quality of the environment [6]. Escherichia coli, Enterococcus faecalis, and Enterococcus faecium are habitants of the environment and animal guts; all associated with gastrointestinal infections and also a measure of fecal contamination [7,8]. Edible offal spoil fast owing to their functional structures and are often tainted with pathogenic bacteria [9]. Some parts of the world prepare slightly cooked offal dishes, a practice that may cause foodborne illnesses. Campylobacteriosis was reported in New Zealand and the U.S. due to consumption of undercooked liver [10]. Often restaurants serve undercooked liver to retain nutritional benefits, which could cause illness as liver tissue may be contaminated with Campylobacter [11] and other foodborne pathogens. Organs including liver and tripe should be prepared at a minimum internal temperature of $160^{\circ} \mathrm{F}\left(71.1^{\circ} \mathrm{C}\right)$.

Antimicrobial resistance in food animals is a major concern due to the potential dissemination of resistant bacteria to humans via the food chain [12]. According to Mcewen and Fedorka-Cray [13], antimicrobial-resistant bacteria may leak and contaminate meat during slaughtering and could transfer to humans through food. Bosilevac et al. [14] report that meats are a cradle and vehicle for dispersion of antibiotic-resistant bacteria to humans. Since edible offal has received considerable focus due to its nutritious qualities [15], it is essential to evaluate their microbiological quality. Therefore, this study assessed the prevalence of antimicrobial-resistant bacteria from retailed offal and muscle meats in Nashville, Tennessee. Nashville is a city with an influx of immigrants and notably, some chain retail stores have offal sections to accommodate individuals embracing offal-based dishes. Again, Nashville is in the southern U.S., also accommodating use in traditional southern foods.

\section{Materials and Methods}

\subsection{Sample Collection and Preparation}

A total of 160 edible offal (chicken liver $=72$; beef liver $=44$; and beef tripe $=44$ ) and 188 muscle meats (chicken wing $=72$; ground chicken $=72$; and ground beef $=44$ ) were purchased from three retail stores in Nashville, over 6 months from August 2017 to January 2018. Meats per sample type were purchased in duplicates at each selected store and identified as MSA $(n=2), \operatorname{MSB}(n=2)$, and MSC $(n=2)$ to keep their confidentiality. In total, meat samples were purchased from 6 stores. The number of meat samples purchased each week was dependent on availability at the time of collection. All meats were acquired before the best-selling date, labeled with store identification letter, and date of collection. Meats were transported in iceboxes to the laboratory and processed within $2 \mathrm{~h}$ of collection. From each meat sample, 3 sub-samples were prepared and processed for bacterial isolation and identification. Concisely, $25 \mathrm{~g}$ of each sub-sample were aseptically placed in a sterile stomacher bag (Fisher scientific, Pittsburgh, PA USA) into which $225 \mathrm{~mL}$ sterile buffered peptone water (BPW) (Oxoid, Solon, OH, USA) was added. The mixture was homogenized (Stomacher ${ }^{\circledR} 400$ Circulator, Seward, Norfolk, UK) at $230 \mathrm{rpm}$ for $2 \mathrm{~min}$. Prevalence of Salmonella enterica serovar, Campylobacter, Escherichia coli O157:H7, generic Escherichia coli, and enterococci were evaluated from all homogenized samples.

\subsubsection{Detection of Salmonella Enterica serovar}

For pre-enrichment, the homogenized mixture was incubated for $24 \mathrm{~h}$ at $37^{\circ} \mathrm{C}$. Approximately 1 and $0.1 \mathrm{~mL}$ of each pre-enriched sample was added to $10 \mathrm{~mL}$ of Tetrathionate (TT) broth (BD, Franklin Lakes, NJ, USA) and Rappaport-Vassiliadis (RV) broth (BD, Franklin Lakes, NJ, USA), respectively. The TT and RV enrichment cultures were incubated at $37^{\circ} \mathrm{C}$ and $42{ }^{\circ} \mathrm{C}$, respectively for $24 \mathrm{~h}$. After enrichment, $10 \mu \mathrm{L}$ of each sample was streaked in duplicates onto xylose lysine Tergitol 4 (XLT-4; Oxoid) and CHROMagar Salmonella (CAS) agar (Oxoid) plates. After incubation at $37^{\circ} \mathrm{C}$ for $24 \mathrm{~h}$, colonies that were red to yellow with black centers on XLT-4 or mauve (rose to purple) on CAS plates were identified as presumptive Salmonella enterica serovar. Oxidase and Salmonella enterica serovar agglutination tests (FT0203; Oxoid) were additionally used for further 
identification of Salmonella enterica serovar. All presumptive isolates were tested biochemically by using API 20E strips (bioMérieux, Hazelwood, MO, USA). Escherichia coli ATCC 25922, Klebsiella pneumoniae and pneumoniae ATCC 35657 were used as quality strains. Three colonies per plate were selected for API biochemical testing. The isolates with $>90 \%$ confidence level identification were confirmed by PCR.

\subsubsection{Detection of Campylobacter spp.}

For each meat sample, $1 \mathrm{~mL}$ of the homogenized mixture was enriched in $9 \mathrm{~mL}$ of sterile Bolton Broth (CM 0983; Oxoid, Solon, OH, USA) with CCDA Lysed Horse Blood (SR0048C; Oxoid, Solon, OH, USA) and a selective supplement (SR0183E; Oxoid, Solon, OH, USA). CampyGen (CN0025A; Oxoid, Solon, OH, USA) was introduced to provide microaerophilic conditions desirable for Campylobacter isolation. After incubation at $42^{\circ} \mathrm{C}$ for $48 \mathrm{~h}$, a loop $(10 \mu \mathrm{L})$ of each enriched sample was streaked in duplicates onto Campylobacter blood-free agar (CM 0739; Oxoid, Solon, OH, USA) with CCDA selective supplement (SR155E; Oxoid, Solon, OH, USA). After incubation at $42{ }^{\circ} \mathrm{C}$ for $48 \mathrm{~h}$, plates were examined for morphologically typical of Campylobacter colonies (greyish, often with a metallic sheen, flat, and moist with a tendency to spread). Presumptive Campylobacter colonies were confirmed by Gram staining, oxidase, and catalase tests. The presumed isolates were further subjected to standard phenotypic tests using the API CAMPY system (bioMérieux, Hazelwood, MO, USA) and Campylobacter confirm latex Kit (Scimedx, Denville, NJ, USA).

\subsubsection{Detection of Generic Escherichia coli and Escherichia coli O157:H7}

Homogenized samples were incubated for $24 \mathrm{~h}$ at $37^{\circ} \mathrm{C}$ for pre-enrichment. Approximately, $50 \mathrm{~mL}$ of each pre-enriched sample was mixed with $50 \mathrm{~mL}$ of double-strength MacConkey broth (Oxoid, Solon, $\mathrm{OH}, \mathrm{USA})$ and incubated at $35^{\circ} \mathrm{C} \pm 2{ }^{\circ} \mathrm{C}$ for $24 \mathrm{~h}$. After incubation, a loop $(10 \mu \mathrm{L})$ of each sample was streaked in duplicates onto Eosin-Methylene Blue (EMB) agar plates (BD, Franklin Lakes, NJ, USA) for Escherichia coli and Sorbitol MacConkey agar (CM0813; Oxoid, Solon, OH, USA) supplemented with cefixime $(50 \mathrm{ng} / \mathrm{mL}$ ) and potassium tellurite $(25 \mathrm{mg} / \mathrm{mL}$ ) supplement (SR0172E; Oxoid, Solon, $\mathrm{OH}$, USA) for Escherichia coli O157:H7. Consequently, inoculated plates were then incubated at $37^{\circ} \mathrm{C}$ for $24 \mathrm{~h}$. Isolates with a typical Escherichia coli morphology and blue/black with a greenish metallic sheen on EMB were identified as presumptive Escherichia coli. Escherichia coli colonies were randomly selected and confirmed using the API 20E identification system (bioMerieux, Hazelwood, MO, USA). Colorless, circular, and entire edge colonies with brown centers on the Sorbitol MacConkey agar were identified as presumptive Escherichia coli O157:H7. Colonies were further screened for the presence of the O157 antigen by Escherichia coli O157 latex test kit (DR0620M, Oxoid, Solon, OH, USA). Presumptive colonies were inoculated onto nutrient agar plates and incubated at $37^{\circ} \mathrm{C}$ for $24 \mathrm{~h}$ further investigations.

\subsubsection{Detection of Enterococcus spp.}

Each homogenized sample $(1 \mathrm{~mL})$ was enriched in $9 \mathrm{~mL}$ of sterile Enterococcosel Broth (EB) (BD, Franklin Lakes, NJ, USA) and incubated at $37^{\circ} \mathrm{C}$ for $24 \mathrm{~h}$. Next, $10 \mu \mathrm{L}$ of Enterococcosel broth from positive samples (black) was streaked onto Enterococcosel Agar (EA) plates and incubated at $37^{\circ} \mathrm{C}$ for 24 to $48 \mathrm{~h}$. Colonies translucent with brownish-black to black zones on Enterococcosel Agar were identified as Enterococcus spp. The phenotypic test for presumptive enterococci isolates was based on morphology and biochemical traits: catalase testing, gram-positive, bile-esculin, and L-pyrrolidonyl- $\beta$-naphthylamide activity. In addition, isolates were subjected to the API 20 Strep (bioMérieux, Hazelwood, MO, USA) and results were interpreted using the API web software (version 4.0, bioMe'rieux, Hazelwood, MO, USA).

\subsection{Bacterial DNA Preparation and Bacteria Confirmation}

Salmonella enterica serovar, Escherichia coli O157:H7, generic Escherichia coli, and enterococci isolates were cultivated overnight at $37^{\circ} \mathrm{C}$ in tryptic soy broth (TSB; Difco BD). Campylobacter isolates were 
cultivated in Bolton Broth supplemented with 5\% Lysed Horse Blood (Oxoid SR0048C) and selective supplement (Oxoid SR0183E). Plates were then incubated at $42{ }^{\circ} \mathrm{C}$ for $48 \mathrm{~h}$ under previous described micro-aerobic conditions. DNA was extracted from overnight cultures $\left(>5 \times 10^{6}\right.$ cells) using the PureLink Genomic DNA Mini Kit (Life Technologies, Grand Island, NY, USA). DNA concentrations and integrity were determined by using a NanoDrop 2000 (Thermo Scientific, Pittsburgh, PA, USA) and agarose gel electrophoresis, respectively. A PCR CORE Kit (Sigma, St. Louis, MO, USA) was used in this study. Each reaction mixture $(25 \mu \mathrm{L})$ contained $125 \mathrm{ng}$ of DNA template, $0.5 \mu \mathrm{M}$ each forward and reverse primers, $400 \mu \mathrm{M}$ deoxynucleoside triphosphates, $3 \mathrm{mM} \mathrm{MgCl} 2,2.5 \mu \mathrm{L}$ of 10x PCR buffer, and $2.5 \mathrm{U}$ Taq DNA polymerase. The sequences of primer pair used for targeting Salmonella enterica serovar target gene $(o m p C)$ was 5'-ATCGCTGACTTATGCAATCG-3 and 5'-CGGGTTGCGTTATAGGTCTG-3' [16], whereas the primer pair used for targeting Campylobacter spp. (16SrRNA) was $5^{\prime}$-ATCT AATGGCTTAACCATTAAAC-3' and 5'-GGACGGTAACTAGTTTAGTATT-3' [17]. Escherichia coli O157:H7 ( $r f b E)$ primer pair was 5'-CAGGTGAAGG TGGAATGGTTGTC-3' and $5^{\prime}$ TTAGAATTGAGACCATCCAATAAG-3' [18], for Escherichia coli (uidA) the primer pair was $5^{\prime}$-TGGTAATTACCGACGAAAACGGC-3' and 5'-TGGTAATT ACCGACGAAAACGGC-3' [19], and Enterococcus spp. (Tuf) was 5'-TACTGACAAACCATTCATGATG-3' and 5' AACTTCGTCACCAACGCG AAC-3 [20]. PCR was performed by using a GeneAmp PCR system 2700 thermal cycler (Applied Biosystems, Foster City, CA). Consequently, the PCR products were electrophoresed in agarose gel stained with $0.5 \mu \mathrm{g} / \mathrm{mL}$ of ethidium bromide (Sigma-Aldrich, Madrid, Spain) and photographed under UV light.

\subsection{Antibiotic Resistant Profiles}

Antimicrobial susceptibility was performed in accordance with the standard Kirby disk diffusion method recommended by the Clinical and Laboratory Standards Institute (CLSI, 2016). Antimicrobial disks (BD) used, with strength in parentheses were: amoxicillin/clavulanic acid (AMC; 20/10 $\mu \mathrm{g}$ ), cefotaxime (CTX; $30 \mu \mathrm{g})$, ceftazidime (CAZ; $30 \mu \mathrm{g})$, ceftriaxone (CRO; $30 \mu \mathrm{g})$, chloramphenicol (CHL; $30 \mu \mathrm{g}$ ), ciprofloxacin (CIP; $5 \mu \mathrm{g}$ ), erythromycin (ERY; $15 \mu \mathrm{g}$ ), imipenem (IPM; $10 \mu \mathrm{g}$ ), tetracycline (TET; $5 \mu \mathrm{g}$ ), and vancomycin (VAN; $30 \mu \mathrm{g}$ ). A total of 231 bacteria isolates were tested against selected antimicrobials. Briefly, Salmonella enterica serovar, Escherichia coli, and enterococci overnight cultures were adjusted to $0.5 \mathrm{McF}$ arland standard and spread evenly on Mueller-Hinton (MH) agar plates (Difco, BD). Antibiotic susceptibility disks were then placed on $\mathrm{MH}$ plates and incubated for $24 \mathrm{~h}$ at $37^{\circ} \mathrm{C}$. For Campylobacter, $\mathrm{MH}$ broths cultured at $42^{\circ} \mathrm{C}$ for $48 \mathrm{~h}$ were plated on $\mathrm{MH}$ agar supplemented with $5 \%$ Lysed Horse Blood. MH plates were then incubated in a microaerophilic atmosphere for $48 \mathrm{~h}$ at $42{ }^{\circ} \mathrm{C}$. The zones of inhibition were interpreted according to CLSI guidelines [21]. Staphylococcus aureus ATCC 25923 and Escherichia coli ATCC 25922 were used as quality control organisms. Reference standard bacterial strains were tested concurrently as controls.

\subsection{Statistical Analysis}

The data was captured in Microsoft Excel ${ }^{\circledR}$ (Microsoft Corporation, Redmond, WA, USA) USA) and analyzed using the analysis of variance of SAS for Windows (version 6.12; SAS Institute, Inc., Cary, NC, USA) and chi-square test. The antibiotic resistance values were expressed as percentages and statistical significance was set at $p$-values of less than 0.05 .

\section{Results and Discussion}

\subsection{Pathogenic Bacteria: Salmonella enterica serovar and Campylobacter spp.}

Salmonella enterica serovar and Campylobacter spp. were recovered from edible offal and muscle meats as displayed in Table 1 . The prevalence of Salmonella enterica serovar at $9.7 \%$ was significantly $(p<0.05)$ high as compared to other offal meats, notably none was recovered from beef liver and beef trips. Salmonella enterica serovar was also present in chicken wings (4.2\%) and ground chicken $(6.9 \%)$. 
There was no significant difference of Salmonella enterica serovar found in ground beef. However, no significant $(p>0.05)$ differences in the occurrence of this pathogen between edible offal $(4.4 \%)$ and muscle meats $(4.3 \%)$.

Table 1. Prevalence (\%) of pathogenic and indicator bacteria in retail edible offal and muscle meats.

\begin{tabular}{|c|c|c|c|c|c|c|c|c|}
\hline \multirow{2}{*}{ Bacterial Species ${ }^{A}$} & \multicolumn{4}{|c|}{ No. $(\%)$ of Edible Offal ${ }^{B}$} & \multicolumn{4}{|c|}{ No. $(\%)$ of Muscle Meat ${ }^{B}$} \\
\hline & CL $(n=72)$ & BL $(n=44)$ & BT $(n=44)$ & Total $(n=160)$ & $\mathrm{CW}(n=72)$ & GC $(n=72)$ & GB $(n=44)$ & Total $(n=188)$ \\
\hline Salmonella enterica serovar & $7(9.7)^{\text {ay }}$ & $0(0.0)^{\mathrm{cy}}$ & $0(0.0)^{\mathrm{cy}}$ & $7(4.4)$ aby & $3(4.2)$ aby & $5(4.2)$ aby & $0(0.0)^{\mathrm{cy}}$ & $8(4.3)$ aby \\
\hline Campylobacter & $0(0.0)$ by & $3(6.9)$ ay & $0(0.0)$ by & $3(1.9)$ aby & $0(0.0)$ by & $1(1.4)^{\text {aby }}$ & $1(2.3)^{\text {aby }}$ & 2 (1.1) aby \\
\hline Escherichia coli & $67(93.1)$ ax & $28(63.6)^{b x}$ & $32(72.7) \mathrm{abx}$ & $127(79.4)^{a b x}$ & $67(93.1)$ ax & $68(94.4)^{\text {ax }}$ & $33(75.0)$ abx & $168(89.4)^{\text {ax }}$ \\
\hline enterococci & $70(97.2)^{a x}$ & $36(81.8)^{b x}$ & $35(79.5)^{b x}$ & $141(88.1)^{\mathrm{bx}}$ & $72(100.0)^{a x}$ & $72(100.0)^{a x}$ & $36(81.8)^{\mathrm{bx}}$ & $180(95.7)^{\mathrm{ax}}$ \\
\hline
\end{tabular}

${ }^{A}$ Bacterial species isolated from the edible offal and muscle meat. ${ }^{B}$ Edible offal included chicken liver (CL), beef liver (BL), and beef tripe (BT); Muscle Meat included chicken wing (CW), ground chicken (GC), and ground beef (GB). ${ }^{\text {a-c }}$ Mean percentages in the same row followed by different letters are significantly different $(p<0.05)$. ${ }^{x-y}$ Mean percentages in the same column followed by different letters are significantly different $(p<0.05)$.

In a previous study, the prevalence of Salmonella in retail chicken and ground turkey was reported at $9.1 \%$ and $5.5 \%$, respectively [22]. In addition, Erickson [23] documented a lower (2\%) prevalence of Salmonella in ground turkey. However, Phan et al. [24] observed a higher Salmonella prevalence $(21.0 \%)$ in chicken meat. According to Wideman et al. [25], the prevalence of Salmonella-contaminated poultry products has dropped significantly due to major and improved alterations in handling of poultry in processing plants. Although none of the beef liver, beef tripe, and ground beef samples were positive for Salmonella enterica serovar in our study, this pathogen has been detected at a rate of $3.8 \%$ and $2.4 \%$ in beef from retail stores and federally inspected establishments, respectively [26]. Murakami et al. [27] also reported 1.5\% Salmonella enterica serovar occurrence on cattle offal in Fukuoka, Japan.

In our study, the presence of Salmonella enterica serovar in both edible offal and muscle meats was confirmed by PCR (Figure 1).

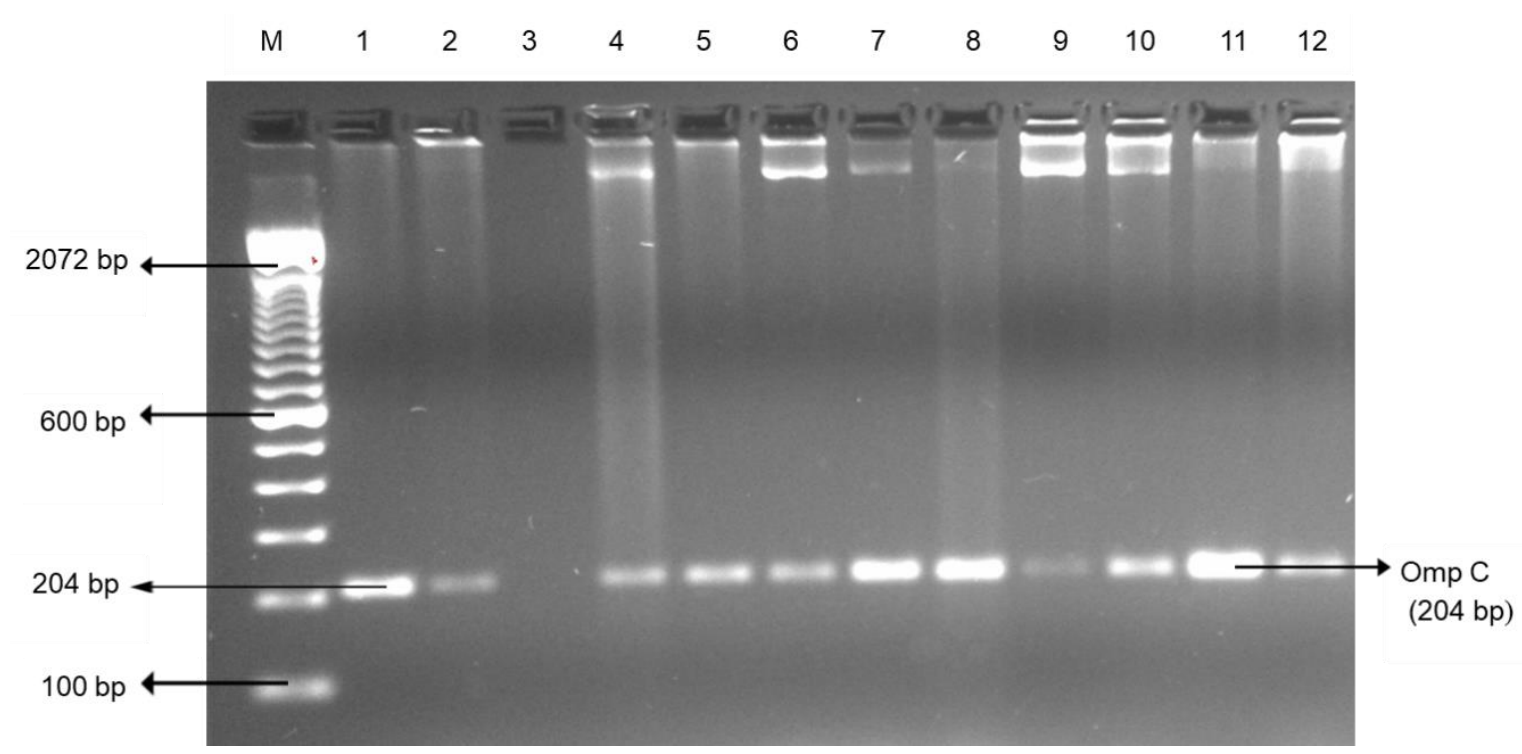

Figure 1. Representative PCR results of Salmonella enterica serovar (ompC) isolated from the edible offal and muscle meat. Lane M: 100 bp DNA marker; lane 1-2: positive control; lane 3: negative control; and lane 4-12: positive samples.

Generally, as displayed in this study and Zhang et al. [28] investigation, Salmonella enterica serovar is frequently found in poultry meats and less in bovine meats. Painter et al. [29] stated that 10-29\% of salmonellosis infections in the U.S. are associated with poultry. Salmonella enterica serovar is a significant foodborne pathogen in raw meats, mostly in chicken products, and will continue to be a challenge in food chain [30]. 
Low Campylobacter frequency was observed in ground beef (2.3\%) and the ground chicken $(1.4 \%)$ as shown in Table 1. Overall, no significant difference was observed in Campylobacter occurrence between edible offal and muscle meats. However, specifically beef liver (6.9\%) showed a significantly higher prevalence $(p<0.05)$ than ground chicken $(1.4 \%)$ and ground beef $(2.3 \%)$. Trokhymchuk et al. [31] reported a higher Campylobacter rate (16.2\%) in retail ground beef than in our study (2.3\%). Our results also show $6.9 \%$ of Campylobacter on the beef liver, relatively in agreement with Enokimoto et al. [32] study that displayed a 5\% prevalence. However, other studies have reported higher Campylobacter occurrences of 78\% [33] and 69\% [34]. The elevated Campylobacter incidence in retail beef liver might be due to cross-contamination since they are recovered from several cows and amassed together [33]. Ghafir et al. [35] also suggested that the raised level of Campylobacter recovery from liver may be due to elevated moisture content, which provides protection to the foodborne pathogen. The risk of Campylobacter in beef liver could also be magnified by preparing lightly to evade charring and undesired taste [35]. According to Vipham et al. [36], retail ground beef storage environment could also favor Campylobacter survival. In the current study, Campylobacter spp. on edible offal and muscle meats was confirmed as displayed in Figure 2.

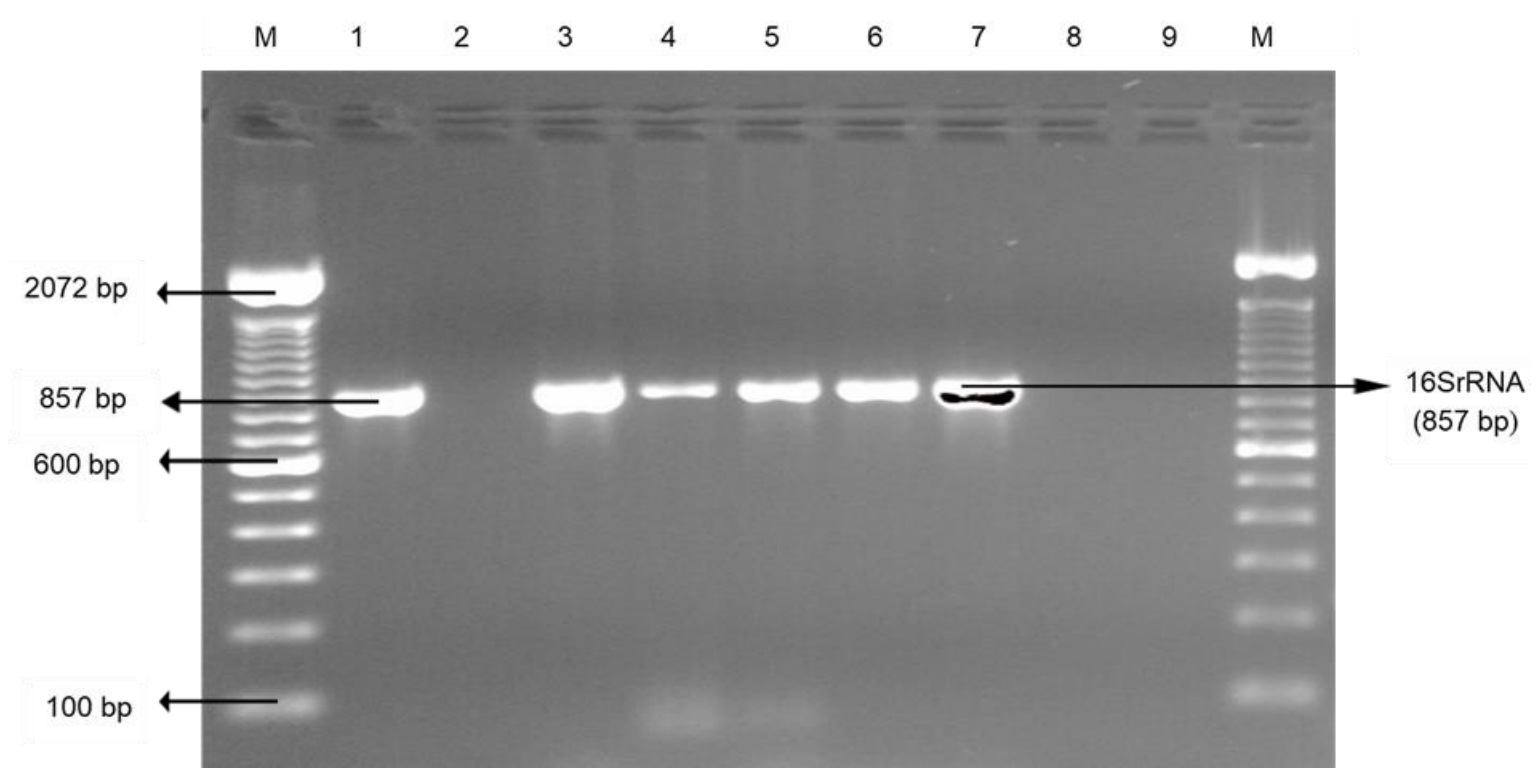

Figure 2. Representative PCR results of Campylobacter (16SrRNA) isolated from the edible offal and muscle meat. Lane M: 100 bp DNA marker; lane 1: positive control; lane 2: negative control; and lane 3-9: samples (lane 3-7: positive samples; lane 8-9: negative sample).

Although there have been improvements in handling practices, retail meat and liver products may be tainted with Campylobacter at the slaughterhouse [37]. Campylobacter has the potential to survive severe environments through utilizing multiple survival mechanisms [38]; hence, potential for future outbreaks owing to the inclination for undercooked liver [39] and other meat products. It is also documented that Campylobacteriosis outbreaks have been linked to contaminated retail liver products worldwide [40,41]. In our study, there were no Escherichia coli O157:H7 positive edible offal or muscle meats (Figure 3).

\subsection{Indicator Bacteria: Escherichia coli and enterococci}

Escherichia coli and enterococci were observed in all edible offal and muscle meats as displayed in Table 1. Overall, muscle meats presented significantly $(p<0.05)$ higher Escherichia coli occurrence $(89.4 \%)$ than in edible offal $(79.4 \%)$ (Table 1$)$. Our findings are supported by the Food Authority reporting a higher occurrence of Escherichia coli in beef cuts than beef offal [42]. In reference to edible offal, the frequency of Escherichia coli was significantly $(p<0.05)$ higher in chicken liver $(93.1 \%)$ as 
compared to beef tripe (72.7\%), and beef liver (63.6\%). However, in another report, Escherichia coli was isolated at $40 \%$ from beef liver [43]. From the statistical analysis, it can be concluded that prevalence levels of Escherichia coli were not significantly $(p>0.05)$ different in the ground chicken $(94.4 \%)$ and chicken wings (93.1\%).

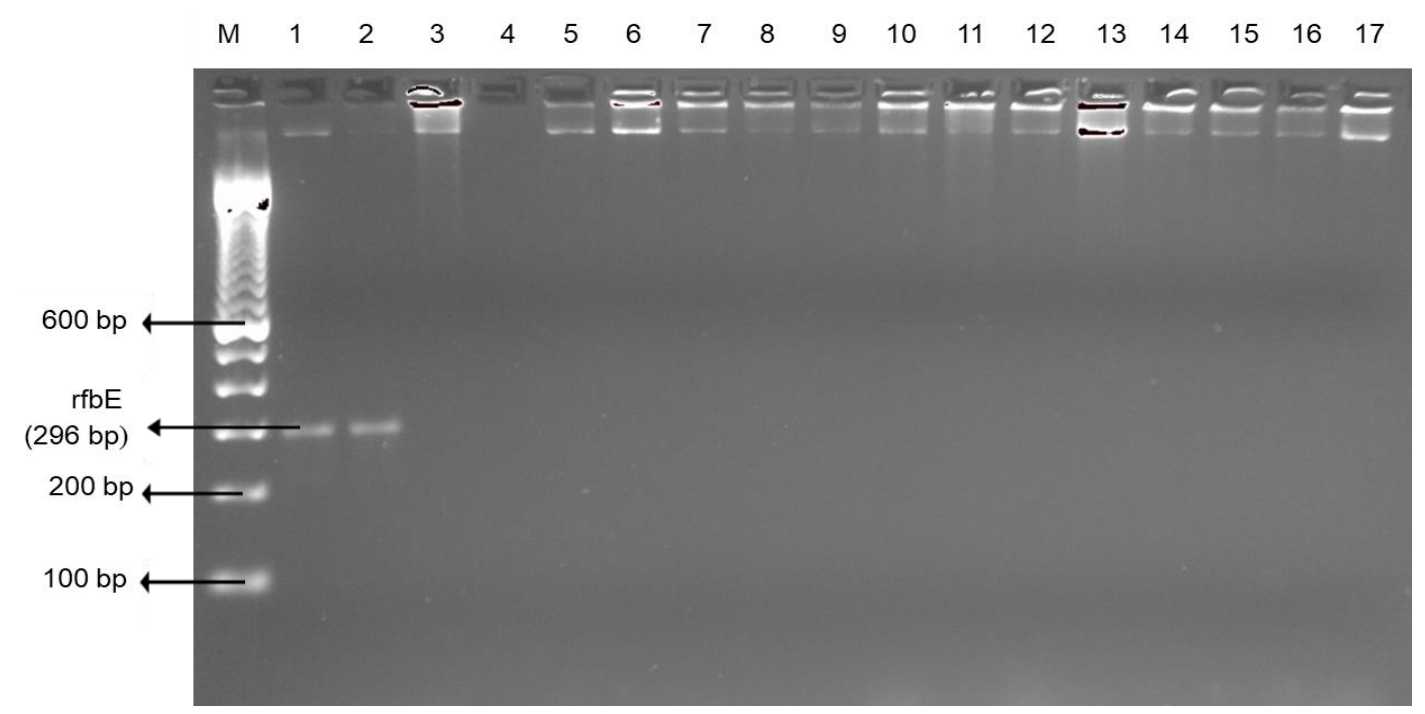

Figure 3. Representative PCR results of E. coli O157:H7 (rfbE) isolated from the edible offal and muscle meat. Lane M: 100 bp DNA marker; lane 1-2: positive control; lane 3: negative control; and lane 4-17: samples. All samples were negative for E. coli O157:H7.

Chicken wings and ground chicken presented the highest enterococci (100\%), followed by chicken liver $(97.2 \%)$, beef liver, ground beef $(81.8 \%)$, and beef tripe $(79.5 \%)$. Ground beef, beef tripe, and beef liver showed significantly $(p<0.05)$ lower enterococci prevalence than in chicken liver, chicken wing, and ground chicken (Table 1). The occurrence of enterococci in retailed offal and muscle meats is a health concern as it is the third primary source of nosocomial infections in the United States [44]. Improper handling practices of enterococci contaminated meat may result to nosocomial infection. Escherichia coli and enterococci incidence in foods is reflected as an indicator of fecal contamination and occurrence of pathogenic bacteria in the interrelated food items [45]. Figures 4 and 5 are PCR confirmations of Escherichia coli and enterococci occurrence in both edible offal and muscle meats, respectively.

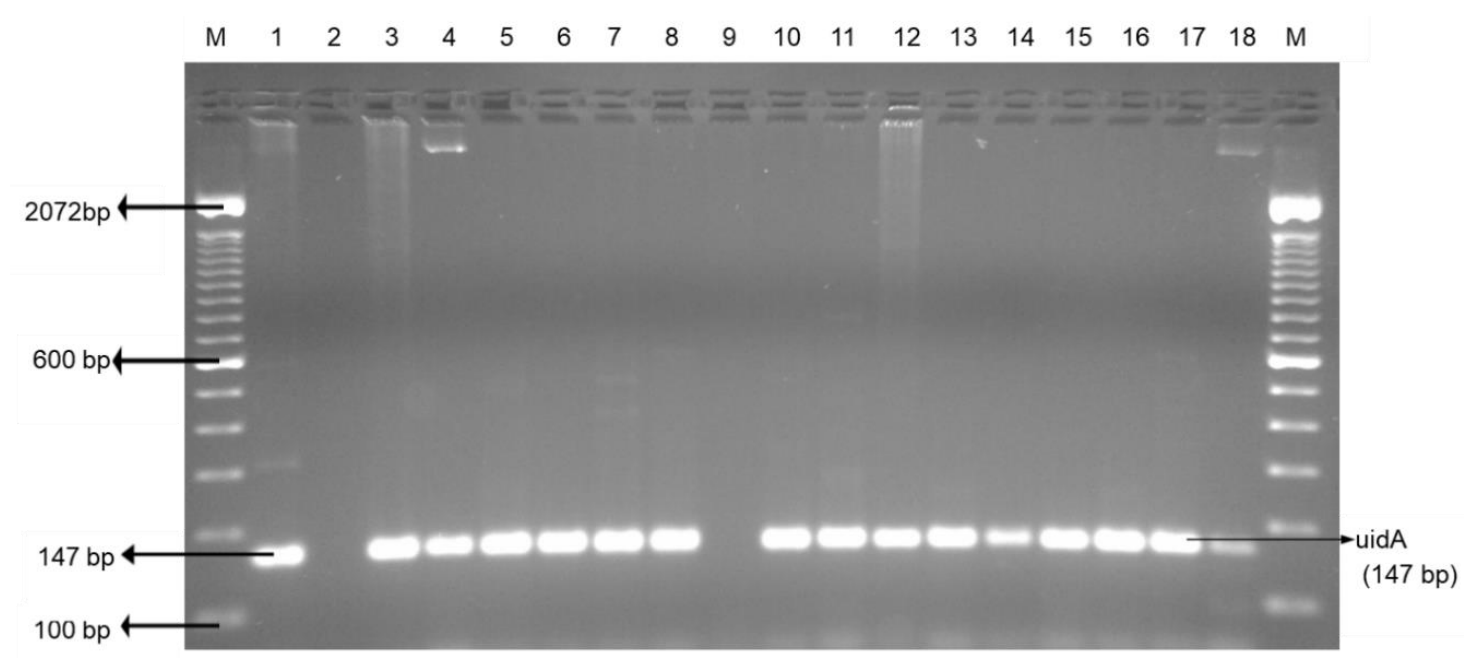

Figure 4. Representative PCR results of E. coli (uidA) isolated from the edible offal and muscle meat. Lane M: 100 bp DNA marker; lane 1: positive control; lane 2: negative control; and lane 3-18: samples; (lane 3-8 and lane 10-18: positive samples; lane 9: negative sample). 


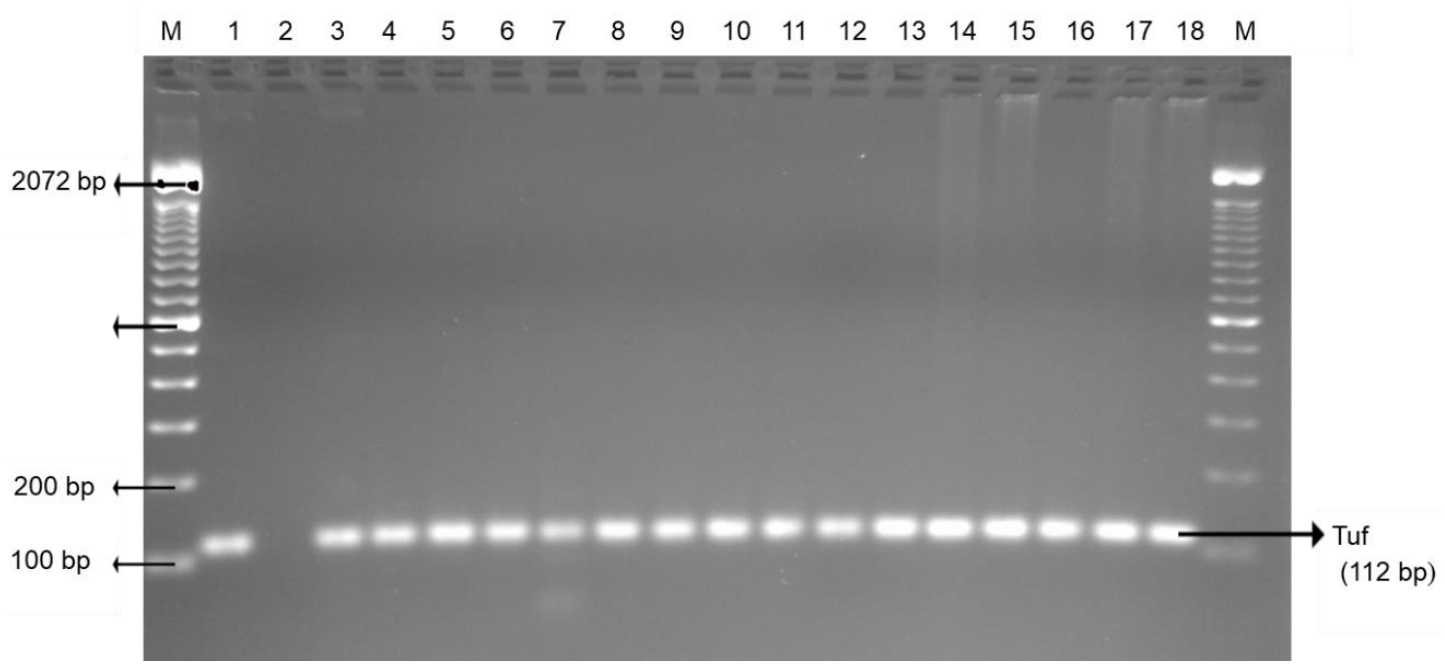

Figure 5. Representative PCR results of enterococci (Tuf) isolated from the edible offal and muscle meat. Lane M: 100 bp DNA marker; lane 1: positive control; lane 2: negative control; and lane 3-18: positive samples.

\subsection{Antimicrobial Drug Resistance in Pathogenic Bacteria}

Detailed presentations of antimicrobial-resistant bacteria in edible offal and muscle meats are shown in Table 2. Phenotypic screening of antimicrobial resistance among pathogenic bacteria in our study revealed resistance to essential antimicrobials in human medicine [46]. Salmonella enterica serovar recovered from edible offal and muscle meats demonstrated resistance to at least six and eight antibiotics, respectively. Salmonella enterica serovar recovered from muscle and offal meats was multidrug-resistant (MDR). Salmonella enterica serovar significantly $(p<0.05)$ showed high resistance to vancomycin $(100 \%$ and $100 \%)$, erythromycin $(100 \%$ and $100 \%)$, and tetracycline $(85.7 \%$ and $100 \%)$ as compared to chloramphenicol $(71.4 \%$ and $62.5 \%)$, ceftriaxone $(57.1 \%$ and $62.5 \%)$, and cefotaxime $(42.9 \%$ and $62.5 \%)$ in edible offal and muscle meats, respectively.

Our findings are in agreement with previous a study [47] that documented Salmonella resistance to erythromycin, tetracycline, and amoxicillin/clavulanic acid in retail meats. Resistance to ceftriaxone and cefotaxime was also exhibited by Salmonella enterica serovar isolates $(n=7)$ in our study. Hence, a concern since these drugs are first line therapy for salmonellosis and an option to treat antimicrobial resistant Salmonella in human medicine. Resistance to ciprofloxacin and imipenem was not observed among Salmonella isolates. In a previous report, 92 people in 29 states in the U.S. were infected with MDR Salmonella enterica serovar traced to raw chicken products [48]. The occurrence of Salmonella enterica serovar resistance to clinically important drugs is a challenge; it could translate to the constricted option of Salmonellosis treatment. Salmonella gastroenteritis is typically a self-limiting disease; however, antibiotics are suggested for patients at a greater threat for invasive diseases [49].

No significant $(p>0.05)$ difference in antimicrobial resistance was observed in Campylobacter (Table 2) isolates $(n=3)$ in all antibiotics tested in this study. Campylobacter showed high resistance to cefotaxime $(100 \%)$, ceftriaxone $(100 \%)$, erythromycin $(100 \%)$, and vancomycin $(100 \%)$. Our results are in agreement with Ge et al. [50] study that noted resistance to tetracycline (82\%), erythromycin (54\%), and ciprofloxacin (35\%) among Campylobacter isolates from retail chicken. Campylobacter resistance for other antibiotics was noted to tetracycline (33.3\% and $0 \%$ ) and ciprofloxacin $(100 \%$ and $50 \%$ ) for offal and muscle meats, respectively. Research has revealed a major link between Campylobacter strains presenting resistance to tetracycline and ciprofloxacin [51]. 
Table 2. Prevalence of antibiotic resistant bacteria from the edible offal and muscle meats.

\begin{tabular}{|c|c|c|c|c|c|c|c|c|c|c|c|}
\hline \multirow{2}{*}{ Bacterial Species $^{\mathrm{A}}$} & \multirow{2}{*}{ Isolates $(\mathrm{n}=116)$} & \multicolumn{10}{|c|}{ No. (\%) of Bacteria Isolates in the Edible Offal Resistant to Antimicrobial Agents ${ }^{B}$} \\
\hline & & AMC & CTX & CAZ & CRO & CHL & CIP & ERY & IPM & TET & VAN \\
\hline \multicolumn{12}{|l|}{ Offal meats } \\
\hline Salmonella enterica serovar & 7 & $0(0.0)^{\mathrm{c}}$ & $3(42.9)^{a b}$ & $0(0.0)^{\mathrm{c}}$ & $4(57.1)^{a b}$ & $5(71.4)^{a}$ & $0(0.0)^{\mathrm{c}}$ & $7(100)^{a}$ & $0(0.0)^{c}$ & $6(85.7)^{a}$ & $7(100)^{a}$ \\
\hline Campylobacter & 3 & $0(0)^{\mathrm{a}}$ & $3(100)^{a}$ & $0(0)^{\mathrm{a}}$ & $3(100)^{a}$ & $0(0)^{a}$ & $3(100)^{a}$ & $3(100)^{a}$ & $0(0)^{\mathrm{a}}$ & $1(33.3)^{\mathrm{a}}$ & $3(100)^{a}$ \\
\hline Escherichia coli & 53 & $53(100)^{a}$ & $39(73.6) \mathrm{ab}$ & $9(17)^{c}$ & $39(73.6)$ ab & $36(67.9)^{a b}$ & $18(34) \mathrm{bc}$ & $53(100)^{\text {a }}$ & $0(0)^{c}$ & $53(100)^{\text {a }}$ & $53(100)^{a}$ \\
\hline Enterococci & 53 & $0(0)^{\mathrm{c}}$ & $51(96.2)^{\mathrm{a}}$ & $51(96)^{a}$ & $52(98)^{\text {a }}$ & $9(17)^{b c}$ & $32(60)^{a b}$ & $51(96.2)^{\text {a }}$ & $0(0)^{c}$ & $49(92.5)^{\mathrm{a}}$ & $40(75.5)^{\mathrm{ab}}$ \\
\hline Total & 116 & $53(46) b c$ & $96(83)^{\mathrm{ab}}$ & $60(52)^{b c}$ & $98(84.5)^{a b}$ & $50(43.1)^{b c}$ & $53(46)^{b c}$ & $114(98.3)^{a}$ & $0(0)^{c}$ & $109(94)^{\mathrm{a}}$ & $103(88.8)^{a b}$ \\
\hline \multicolumn{12}{|l|}{ Muscle meats } \\
\hline Salmonella enterica serovar & 8 & $2(25) \mathrm{bc}$ & $5(62.5)^{a b}$ & $2(25) \mathrm{bc}$ & $5(62.5)^{a b}$ & $5(62.5)^{a b}$ & $0(0.0)^{\mathrm{c}}$ & $8(100)^{a}$ & $0(0)^{c}$ & $8(100)^{\mathrm{a}}$ & $8(100)^{a}$ \\
\hline Escherichia coli & 51 & $47(92.2)^{\mathrm{a}}$ & $26(51)^{a b}$ & $9(17.7)^{c}$ & $28(55)^{a b}$ & $28(55)^{\mathrm{ab}}$ & $14(26)^{b c}$ & $51(100)^{a}$ & $1(2)^{c}$ & $51(100)^{\mathrm{a}}$ & $51(100)^{a}$ \\
\hline Enterococci & 54 & $1(1.9)^{\mathrm{c}}$ & $50(92.6)^{a}$ & $49(90.7)^{\mathrm{a}}$ & $51(94.4)^{\mathrm{a}}$ & $27(50)^{a b}$ & $49(90.7)^{a}$ & $53(98.1)^{a}$ & $0(0)^{c}$ & $54(100)^{\mathrm{a}}$ & $45(83.3)^{a}$ \\
\hline Total & 115 & $50(43.5) b c$ & $83(71.2) \mathrm{b}$ & $60(52.2) b c$ & $86(74.8)^{\mathrm{b}}$ & $62(53.9) \mathrm{bc}$ & $64(55.7) \mathrm{bc}$ & $114(99.1)^{a}$ & $1(0.9)^{\mathrm{c}}$ & $113(98.3)^{a}$ & $106(92.2)^{\mathrm{a}}$ \\
\hline
\end{tabular}

A Bacterial species isolated from the edible offal. ${ }^{\mathrm{B}}$ Ten selected antibiotics for antimicrobial susceptibility test: Amoxicillin/Clavalanic acid (AMC); Cefotaxime (CTX); Ceftazidime (CAZ); Ceftriaxone (CRO); Chloramphenicol (CHL); Ciprofloxacin (CIP); Erythromycin (ERY); Imipenem (IPM); Tetracycline (TET); and Vancomycin (VAN). ${ }^{a-c}$ Mean percentages in the same row followed by different letters are significantly different $(p<0.05)$. 
Resistance to erythromycin and ciprofloxacin is a major health concern since these drugs are used in the treatment of Campylobacter infections [52]. The upsurge prevalence of ciprofloxacin-resistant Campylobacter in retail poultry meat was also reported in Denmark [53] Spain, Germany, Italy, Holland, and Austria [54]. Nisar et al. [55] also documented Campylobacter resistance to ciprofloxacin. None of the Campylobacter isolates in this study were resistant to amoxicillin/clavulanic acid, ceftazidime, and imipenem. To avert antibiotic-resistant Campylobacter in edible offal and other meats from infecting consumers, chefs and other food preparers must adhere to basic food hygiene practices while handling and preparing meats. Suzuki and Yamamoto [56] reported that Campylobacter is frequently associated with the handling and consumption of meat products, especially raw poultry.

\subsection{Antimicrobial Drug Resistance in Escherichia coli and Enterococci}

Antimicrobial resistance of Escherichia coli from edible offal and muscle meats was observed to clinically important antimicrobials, notably amoxicillin/clavulanic (100\% and $92.2 \%)$, ceftriaxone (73.6\% and $54.9 \%)$, and ciprofloxacin (34\% and $27.5 \%)$, respectively. Escherichia coli resistance to amoxicillin/clavulanic acid was significantly $(p<0.05)$ higher as compared to ceftriaxone resistance in edible offal and muscle meats (Table 2). Escherichia coli resistance to fluoroquinolones is disturbing, especially ciprofloxacin is important for treating Escherichia coli infections in both humans and animals [57]. Escherichia coli from edible offal and muscle meats significantly $(p<0.05)$ presented high levels of resistance to erythromycin $(100 \%$ and $100 \%)$, tetracycline $(100 \%$ and $100 \%)$, and vancomycin $(100 \%$ and $100 \%)$ as compared to ciprofloxacin $(34 \%$ and $27.5 \%)$, and ceftazidime (17\% and $17.7 \%)$, respectively. Notably, only one Escherichia coli isolate from muscle meat was resistant to imipenem.

Our findings suggest that antibiotic-resistant Escherichia coli was prevalent in retail beef liver. This is a health risk since edible offal is often undercooked to preserve nutrient content [58]. Epidemiological records have indicated food poisoning linked to Escherichia coli O157:H7 from beef liver in Japan [59]. Our findings show that edible offal is contaminated with antimicrobial-resistant bacteria, therefore it is essential for consumers to adhere to food safety practices while preparing offal dishes. The presence of multidrug-resistant Escherichia coli on meats is an impending challenge in infectious diseases. Escherichia coli capability to survive and attain resistance in the guts of animals has been labeled as a sentinel organism in antimicrobial resistance surveillance programs [60].

Overall, enterococci from edible offal and muscle meats significantly $(p<0.05)$ exhibited high resistance to ceftriaxone (98.1\% and $94.4 \%$ ), cefotaxime $(96.2 \%$ and $90.6 \%)$, and ceftazidime $(96.2 \%$ and $90.7 \%$ ) as compared to amoxicillin/clavulanic acid ( $0 \%$ and $1.9 \%)$, respectively (Table 2$)$. enterococci from edible offal and muscle meats also demonstrated resistance to ciprofloxacin $(60.4 \%$ and $90.7 \%)$ and vancomycin $(75.5 \%$ and $83.3 \%)$, respectively. Ciprofloxacin and vancomycin are antimicrobials of great importance in human medicine [61]. According to Klare et al. [62] and from a medical angle, vancomycin is an essential therapeutic drug against multidrug-resistant enterococci. Despite the fact enterococci are reflected as opportunist pathogens, our findings reflect them as potential reservoirs of antimicrobial resistance. Therefore, it is a health risk for the occurrence of multidrug-resistant enterococci in retail offal and muscle meats. Jackson et al. [63] report that enterococci is a reservoir of antimicrobial resistance genes and has the potential to transfer these genes to other bacteria in the environment. According to Carvalho et al. [64], Escherichia coli and enterococci are reservoirs of antimicrobial-resistant genes that could be disseminated to pathogenic bacteria in the environment. It is essential to place focused effective control measures at decreasing enterococcus in retail meats, since it is a leading cause of nosocomial infections [65]. Agglutination test displayed higher prevalence of both pathogenic and indicator bacteria than PCR method.

\subsection{Multidrug Resistant Patterns of Pathogenic and Indicator Bacteria}

In our study, both pathogenic and indicator bacteria were MDR. According to Nguyen et al. [66], MDR isolate displays resistance to three or more classes of antibiotics. A total of 41 multidrug-resistant profiles were presented among pathogenic and indicator bacteria from retail offal and muscle meats 
(Table 3). Salmonella from offal and muscle meats displayed AMC-CTX-CRO-CHL-ERY-TET-VAN $(0 ; 1)$, CTX-CAZ-CRO-CHL-ERY-TET-VAN $(0 ; 1)$ and CTX-CRO-CHL-ERY-TET-VAN $(2 ; 2)$ resistance patterns, respectively (number of isolates in parenthesis). CTX-CRO-CHL-ERY-TET-VAN and ERY-TET-VAN were the most prevalent $(p<0.05)$ antimicrobial resistance patterns in Salmonella (Table 3). According to our results, it is clear that both edible and muscle meats are potential sources of MDR Salmonella. MDR Salmonella is an emerging public health challenge worldwide and has repetitively been reported in food animals, a consequential exposure to humans through the food chain [66].

Dissimilar drug resistance patterns including CTX-CRO-CHL-ERY-VAN (0; 1), CRO-CHL-ERY-VAN $(0 ; 1)$ were also recorded for Campylobacter from offal and muscle meats, respectively. Our results displayed MDR Campylobacter isolates, a concern and challenge in campylobacteriosis management [67]. None of the antimicrobial resistance patterns were predominant $(p>0.05)$ over other patterns among Campylobacter isolates (Table 3).

Overall, Escherichia coli displayed 10 multidrug resistance patterns. AMC-CHL-ERY-TET-VAN (23; 15), AMC-ERY-TET-VAN $(12 ; 25)$ were the common phenotypes displayed by Escherichia coli on offal and muscle meats, respectively. Other Escherichia coli patterns included AMC-CAZ-CHL-ERY-TET-VAN $(9 ; 2)$ and AMC-CRO-CHL-ERY-TET-VAN $(1 ; 1)$ in offal and muscle meats, respectively. AMC-CHL-ERY-TET-VAN was the most significant $(p<0.05)$ antimicrobial resistance pattern among Escherichia coli isolates from edible offal. On the other hand, Escherichia coli from muscle meat displayed AMC-ERY-TET-VAN pattern which was significantly dominant $(p<0.05)$ compared to other patterns (Table 3 ). The rise of MDR E. coli is disturbing, especially strains causing urinary tract infections [68].

Our findings reveal that Enterococci exhibited the most $(n=22)$ multidrug-resistant patterns. CTX- CAZ-CRO-CHL-CIP-TET (0; 2), CTX-CAZ- CHL- CIP- ERY- TET (0; 2), CTX-CAZ-CRO-TET $(15 ; 6)$, CTX-CAZ-CRO-ERY-TET (10; 9), and CTX-CAZ-CRO-ERY-TET-VAN $(6 ; 8)$ patterns were displayed for enterococci from offal and muscle meats, respectively. Among enterococci isolates, CTX-CAZ-CRO-TET was observed as the most significant $(p<0.05)$ antimicrobial resistance pattern in edible offal and CTX-CAZ-CRO-ERY-TET-VAN for muscle meats. Enterococci infections are a concern to public health owing to the struggle in controlling them with antimicrobials. According to Weiner et al., [69], vancomycin-resistant enterococci (VRE) are utmost baffling to treat, as some exhibit resistance to all accessible antimicrobials used in medical practice. Chloramphenicol resistance was common as indicated by resistance patterns (Table 3) and according to Whichard et al. [70], chloramphenicol is a unique drug that can be applied to monitor and predict multidrug resistance of foodborne pathogens from animals and retail meats. To prevent foodborne illnesses, consumers must embrace hygienic practices, which include recommended storage and cooking temperatures for all meat types [71]. The findings of our study may assist in tracking the emergence of new resistance patterns among pathogenic and indicter organisms in edible offal and also in other meats. 
Table 3. Multidrug resistance patterns of pathogenic and indicator bacteria in edible offal and muscle meat.

\begin{tabular}{|c|c|c|c|}
\hline Bacterial Species ${ }^{\mathrm{A}}$ & Antibiotic Resistance Profiles ${ }^{B}$ & No. $(\%)$ of Edible Offal Isolates ${ }^{C}(n=116)$ & No. $(\%)$ of Muscle Meat Isolates ${ }^{C}(n=115)$ \\
\hline \multirow{9}{*}{$\begin{array}{l}\text { Salmonella enterica serovar } \\
\qquad(\mathrm{n}=15)\end{array}$} & AMC, CTX, CRO, CHL, ERY, TET, VAN & $0(0.0)^{\mathrm{c}}$ & $1(0.9)^{\mathrm{c}}$ \\
\hline & AMC, CHL, ERY, TET, VAN & $0(0.0)^{\mathrm{c}}$ & $1(0.9)^{\mathrm{c}}$ \\
\hline & CTX, CAZ, CRO, CHL, ERY, TET, VAN & $0(0.0)^{c}$ & $1(0.9)^{\mathrm{c}}$ \\
\hline & CTX, CAZ, ERY, TET, VAN & $0(0.0)^{\mathrm{c}}$ & $1(0.9)^{c}$ \\
\hline & CTX, CRO, CHL, ERY, TET, VAN & $2(1.7)^{b c}$ & $2(1.7)^{b c}$ \\
\hline & CTX, CHL, ERY, TET, VAN & $1(0.9)^{c}$ & $0(0.0)^{c}$ \\
\hline & CRO, CHL, ERY, TET, VAN & $1(0.9)^{c}$ & $0(0.0)^{c}$ \\
\hline & ERY, TET, VAN & $2(1.7)^{b c}$ & $2(1.7) b c$ \\
\hline & ERY, VAN & $1(0.9)^{\mathrm{c}}$ & $0(0.0)^{\mathrm{c}}$ \\
\hline \multirow{5}{*}{$\begin{array}{l}\text { Campylobacter } \\
\quad(\mathrm{n}=5)\end{array}$} & CTX, CRO, CHL, ERY, VAN & $0(0.0)^{c}$ & $1(0.9)^{\mathrm{c}}$ \\
\hline & CRO, CHL, ERY, VAN & $0(0.0)^{c}$ & $1(0.9)^{\mathrm{c}}$ \\
\hline & CRO, ERY, VAN & $1(0.9)^{c}$ & $0(0.0)^{\mathrm{c}}$ \\
\hline & CIP, ERY, VAN & $1(0.9)^{c}$ & $0(0.0)^{\mathrm{c}}$ \\
\hline & ERY, VAN & $1(0.9)^{\mathrm{c}}$ & $0(0.0)^{\mathrm{c}}$ \\
\hline \multirow{10}{*}{$\begin{array}{c}\text { E. coli } \\
(\mathrm{n}=104)\end{array}$} & AMC, CTX, CRO, CHL, ERY, TET, VAN & $1(0.9)^{\mathrm{c}}$ & $0(0.0)^{\mathrm{c}}$ \\
\hline & AMC, CTX, ERY, TET, VAN & $0(0.0)^{\mathrm{c}}$ & $1(0.9)^{\mathrm{c}}$ \\
\hline & $\mathrm{AMC}, \mathrm{CAZ}, \mathrm{CRO}, \mathrm{CHL}, \mathrm{ERY}, \mathrm{TET}, \mathrm{VAN}$ & $2(1,7) b c$ & $2(1.7) b c$ \\
\hline & AMC, CAZ, CHL, ERY, TET, VAN & $9(7.8)^{b x}$ & $2(1.7)$ bcy \\
\hline & AMC, CRO, CHL, ERY, TET, VAN & $5(4.3) b c$ & $1(0.9)^{\mathrm{c}}$ \\
\hline & AMC, CHL, CIP, ERY, TET, VAN & $1(0.9)^{\mathrm{c}}$ & $0(0.0)^{c}$ \\
\hline & AMC, CHL, ERY, TET, VAN & $23(19.8)^{a x}$ & $15(13.0)^{\text {aby }}$ \\
\hline & AMC, ERY, IPM, TET, VAN & $0(0.0)^{c}$ & $1(0.9)^{c}$ \\
\hline & AMC, ERY, TET, VAN & $12(10.3)^{\text {aby }}$ & $25(21.7){ }^{a x}$ \\
\hline & ERY, TET, VAN & $0(0.0)^{\mathrm{c}}$ & $4(3.5) \mathrm{bc}$ \\
\hline \multirow{10}{*}{$\begin{array}{c}\text { Enterococci } \\
(\mathrm{n}=107)\end{array}$} & AMC, CTX, CRO, ERY, TET, VAN & $0(0.0)^{\mathrm{c}}$ & $1(0.9)^{\mathrm{c}}$ \\
\hline & CTX, CAZ, CRO, CIP, ERY, TET, VAN & $1(0.9)^{c}$ & $5(4.3) b c$ \\
\hline & CTX, CAZ, CRO, CHL, CIP, TET & $0(0.0)^{c}$ & $2(1.7) b c$ \\
\hline & CTX, CAZ, CRO, CIP, ERY, TET & $2(1.7)^{b c}$ & $0(0.0)^{c}$ \\
\hline & CTX, CAZ, CRO, CIP, TET, VAN & $0(0.0)^{b c}$ & $2(1.7)^{b c}$ \\
\hline & CTX, CAZ, CRO, ERY, TET, VAN & $6(5.2)^{b}$ & $8(7.0)^{b}$ \\
\hline & CTX, CAZ, CHL, CIP, ERY, TET & $0(0.0)^{\mathrm{c}}$ & $2(1.7)^{b c}$ \\
\hline & CTX, CAZ, CRO, CIP, TET & $1(0.9)^{c}$ & $0(0.0)^{c}$ \\
\hline & CTX, CAZ, CRO, ERY, TET & $10(8.6)^{\mathrm{bx}}$ & $9(7.8)^{\text {by }}$ \\
\hline & CTX, CAZ, CRO, TET, VAN & $2(1.7)^{b c}$ & $7(6.1)^{b}$ \\
\hline
\end{tabular}


Table 3. Cont

\begin{tabular}{|c|c|c|c|}
\hline Bacterial Species ${ }^{A}$ & Antibiotic Resistance Profiles ${ }^{B}$ & No. $(\%)$ of Edible Offal Isolates ${ }^{C}(n=116)$ & No. $(\%)$ of Muscle Meat Isolates ${ }^{C}(n=115)$ \\
\hline & CTX, CAZ, CRO, ERY & $2(1.7) \mathrm{bc}$ & $0(0.0)^{\mathrm{c}}$ \\
\hline & CTX, CAZ, CRO, TET & $15(12.9)$ abx & $6(5.2)$ by \\
\hline & CTX, CAZ, CRO, VAN & $3(2.6)^{b c}$ & $0(0.0)^{c}$ \\
\hline & CTX, CAZ, ERY, TET & $2(1.7)^{b c}$ & $0(0.0)^{c}$ \\
\hline & CTX, CAZ, CRO & $0(0.0)^{c}$ & $3(2.6) b c$ \\
\hline & CTX, CAZ, CIP & $2(1.7)^{b c}$ & $0(0.0)^{c}$ \\
\hline & CAZ, CRO, ERY, TET, VAN & $0(0.0)^{c}$ & $1(0.9)^{c}$ \\
\hline & CAZ, CRO, ERY, TET & $2(1.7)^{b c}$ & $0(0.0)^{\mathrm{c}}$ \\
\hline & CAZ, ERY, TET, VAN & $1(0.9)^{c}$ & $0(0.0)^{c}$ \\
\hline & CAZ, CRO, TET & $0(0.0)^{\mathrm{c}}$ & $1(0.9)^{c}$ \\
\hline & CAZ, CRO & $0(0.0)^{c}$ & $3(2.6)^{b c}$ \\
\hline & CAZ, TET & $2(1.7)^{b c}$ & $0(0.0)^{c}$ \\
\hline & CHL, TET, VAN & $1(0.9)^{c}$ & $0(0.0)^{c}$ \\
\hline & ERY, TET, VAN & $1(0.9)^{c}$ & $2(1.7)^{b c}$ \\
\hline & ERY, VAN & $0(0.0)^{c}$ & $2(1.7)^{b c}$ \\
\hline
\end{tabular}




\section{Conclusions}

This study demonstrated that certain isolates of Salmonella enterica serovar, Campylobacter spp., Escherichia coli, and enterococci from edible offal as well as muscle meats were resistant to "critically important antimicrobials (AMC, CTX, CAZ, CRO, CIP, ERY, IPM, and VAN)" or "highly important antimicrobials (CHL and TET)" used in human medicine [72]. The presence of multidrug-resistant pathogenic and indicator bacteria in edible offal suggests periodic monitoring of these meats. Our data reinforced the need to better recognize the role of retail edible offal and muscle meats as sources of MDR bacteria. This data is desirable for improving the food safety of variety meats which are important in southern cuisine and increasing in popularity in several cities as a result of immigrants' influence.

Author Contributions: Conceptualization, S.L. and A.K.-N.; methodology, S.L., A.K.-N., S.N.N., and B.P.; validation, S.L.; formal analysis, S.L. and A.K.-N.; investigation, S.L. and A.K.-N.; resources, A.K.-N.; writing—original draft preparation, S.L.; writing—review and editing, S.L., A.K.-N., M.N., and A.I.M.; visualization, S.L. and A.K.-N.; supervision, A.K.-N.; project administration, A.K.-N.; and funding acquisition, A.K.-N. All authors have read and agreed to the published version of the manuscript.

Funding: This research was funded by United States Department of Agriculture/National Institute of Food and Agriculture. Grant No. 2015-38821-24343.

Acknowledgments: We acknowledge Poultry Science Association (PSA) for the use of the abstract number: 698P presented at the 2019 Annual Meeting Montréal, QC, Canada, 15-18 July 2019.

Conflicts of Interest: The authors declare no conflict of interest. The funders had no role in the design of the study; in the collection, analyses, or interpretation of data; in the writing of the manuscript, or in the decision to publish the results.

\section{References}

1. Alao, B.O.; Falowo, A.B.; Chulayo, A.; Muchenje, V. The potential of animal by-products in food systems: Production, prospects, and challenges. Sustainability 2017, 9, 1089. [CrossRef]

2. Seong, P.N.; Kang, G.H.; Park, K.M.; Cho, S.H.; Kang, S.M.; Park, B.Y.; Moon, S.S.; Van Ba, H. Characterization of Hanwoo bovine by-products by means of yield, physicochemical, and nutritional compositions. Korean J. Food Sci. An. 2014, 34, 434. [CrossRef]

3. Podpečan, B.; Pengov, A.; Vadnjal, S. The source of contamination of ground meat for production of meat products with bacteria Staphylococcus aureus. Slov. Vet. Res. 2007, 44, 25-30.

4. Jribi, H.; Sellami, H.; Mariam, S.; Smaoui, S.; Ghorbel, A.; Hachicha, S.; Benejat, L.; Messadi-Akrout, F.; Mégraud, F.; Gdoura, R. Isolation and Identification of Campylobacter spp. from Poultry and Poultry By-Products in Tunisia by Conventional Culture Method and Multiplex Real-Time PCR. J. Food Prot. 2017, 80, 1623-1627. [CrossRef] [PubMed]

5. Dhama, K.; Rajagunalan, S.; Tiwari, R.; Verma, A.; Singh, S. Food-borne pathogens of poultry having public health significance. Poult. World 2013, 16, 8-12.

6. Chotinantakul, K.; Chansiw, N.; Okada, S. Antimicrobial resistance of Enterococcus spp. isolated from Thai fermented pork in Chiang Rai Province, Thailand. J. Glob. Antimicrob. Resist. 2018, 12, 143-148. [CrossRef] [PubMed]

7. Mellata, M. Human and avian extraintestinal pathogenic Escherichia coli: Infections, zoonotic risks, and antibiotic resistance trends. Foodborne Pathog. Dis. 2013, 10, 916-932. [CrossRef]

8. Tyson, G.H.; Nyirabahizi, E.; Crarey, E.; Kabera, C.; Lam, C.; Rice-Trujillo, C.; McDermott, P.F.; Tate, H. Prevalence and antimicrobial resistance of Enterococci isolated from retail meats in the United States, 2002 to 2014. Appl. Environ. Microbiol. 2018, 84. [CrossRef]

9. Abdalrahman, L.S.; Wells, H.; Fakhr, M.K. Staphylococcus aureus is more prevalent in retail beef livers than in pork and other beef cuts. Pathogens 2015, 4, 182-198. [CrossRef]

10. New Zealand Food Safety (NZFS). Safe Cooking of Livers: Information for Chefs. 2017. Available online: https://www.mpi.govt.nz/food-safety/food-safety-codes-and-standards/good-operating-practice/ documents/safe-cooking-of-livers (accessed on 1 July 2020). 
11. Lanier, W.A.; Hale, K.R.; Allen, L.; White, P.; Bachert, J.; Dewey-Mattia, D.; Geissler, A. Chicken Liver-Associated Illness Outbreaks, United States, 2000-2015-Identifying Opportunities for Prevention; The Council of State and Territorial Epidemiologists: Atlanta, Georgia, 2017.

12. Topp, E. Agriculture and Agri-Food Canada's research program on antimicrobial resistance. Can. Commun. Dis. Rep. 2017, 43, 224-227. [CrossRef]

13. McEwen, S.A.; Fedorka-Cray, P.J. Antimicrobial use and resistance in animals', Clinical infectious diseases: An official publication of the Infectious Diseases. Soc. Am. 2017, 34, S93-S106.

14. Bosilevac, J.M.; Gassem, M.A.; Al Sheddy, I.A.; Almaiman, S.A.; Al-Mohizea, I.S.; Alowaimer, A.; Koohmaraie, M. Prevalence of Escherichia coli O157: H7 and Salmonella in camels, cattle, goats, and sheep harvested for meat in Riyadh. J. Food Prot. 2015, 78, 89-96. [CrossRef]

15. Toldrá, F.; Aristoy, M.C.; Mora, L.; Reig, M. Innovations in value-addition of edible meat by-products. Meat Sci. 2012, 92, 290-296. [CrossRef]

16. Alvarez, J.; Sota, M.; Vivanco, A.B.; Perales, I.; Cisterna, R.; Rementeria, A.; Garaizar, J. Development of a multiplex PCR technique for detection and epidemiological typing of Salmonella in human clinical samples. J. Clin. Microbiol. 2004, 42, 1734-1738. [CrossRef] [PubMed]

17. Rahimi, E.; Ameri, M. Antimicrobial resistance patterns of Campylobacter spp. isolated from raw chicken, turkey, quail, partridge, and ostrich meat in Iran. Food Control 2011, 22, 1165-1170. [CrossRef]

18. Bai, J.; Shi, X.; Nagaraja, T. A multiplex PCR procedure for the detection of six major virulence genes in Escherichia coli O157: H7. J. Microbiol. Methods 2010, 82, 85-89. [CrossRef] [PubMed]

19. Tantawiwat, S.; Tansuphasiri, U.; Wongwit, W.; Wongchotigul, V.; Kitayaporn, D. Development of multiplex PCR for the detection of total coliform bacteria for Escherichia coli and Clostridium perfringens in drinking water. Southeast Asian J. Trop. Med. Public Health 2005, 36, 162-169. [PubMed]

20. Iweriebor, B.C.; Obi, L.C.; Okoh, A.I. Virulence and antimicrobial resistance factors of Enterococcus spp. isolated from fecal samples from piggery farms in Eastern Cape, South Africa. BMC Microbiol. 2015, 15, 136. [CrossRef] [PubMed]

21. Clinical and Laboratory Standards Institute (CLSI). Performance Standards for Antimicrobial Susceptibility Testing, 26th ed.; CLSI Supplement M100S; CLSI: Wayne, PA, USA, 2016.

22. FDA. NARMS Integrated Report: 2014-The National Antimicrobial Resistance Monitoring System: Enteric Bacteria; FDA: White Oak, MD, USA, 2016.

23. Erickson, A.K.; Murray, D.L.; Ruesch, L.A.; Thomas, M.; Lau, Z.; Scaria, J. Genotypic and Phenotypic Characterization of Salmonella Isolated from Fresh Ground Meats Obtained from Retail Grocery Stores in the Brookings, South Dakota, Area. J. Food Prot. 2018, 81, 1526-1534. [CrossRef] [PubMed]

24. Phan, T.T.; Khai, L.T.L.; Ogasawara, N.; Tam, N.T.; Okatani, A.T.; Akiba, M.; Hayashidani, H. Contamination of Salmonella in retail meats and shrimps in the Mekong Delta, Vietnam. J. Food Prot. 2005, 68, 1077-1080. [CrossRef]

25. Wideman, N.; Bailey, M.; Bilgili, S.F.; Thippareddi, H.; Wang, L.; Bratcher, C.; Sanchez-Plata, M.; Singh, M. Evaluating best practices for Campylobacter and Salmonella reduction in poultry processing plants. Poult. Sci. 2016, 95, 306-315. [CrossRef] [PubMed]

26. Samadpour, M.; Barbour, M.W.; Nguyen, T.; Cao, T.M.; Buck, F.; Depavia, G.A.; Mazengia, E.; Yang, P.; Alfi, D.; Lopes, M.; et al. Incidence of enterohemorrhagic Escherichia coli, Escherichia coli O157:H7, Salmonella, and Listeria monocytogenes in retail fresh ground beef, sprouts, and mushrooms. J. Food Prot. 2006, 69, 441-443. [CrossRef] [PubMed]

27. Murakami, K.; Noda, T.; Onozuka, D.; Sera, N. Salmonella in liquid eggs and other foods in Fukuoka Prefecture, Japan. Int. J. Microbiol. 2013. [CrossRef]

28. Zhang, L.; Fu, Y.; Xiong, Z.; Ma, Y.; Wei, Y.; Qu, X.; Zhang, H.; Zhang, J.; Liao, M. Highly-prevalent multidrug-resistant Salmonella from chicken and pork meat at retail markets in Guangdong, China. Front Microbiol. 2018, 9, 2104. [CrossRef]

29. Painter, J.A.; Hoekstra, R.M.; Ayers, T.; Tauxe, R.V.; Braden, C.R.; Angulo, F.J.; Griffin, P.M. Attribution of foodborne illnesses, hospitalizations, and deaths to food commodities by using outbreak data, United States, 1998-2008. Emerg. Infect. Dis. 2013, 19, 407. [CrossRef] [PubMed]

30. Henchion, M.; McCarthy, M.; Resconi, V.C.; Troy, D. Meat consumption: Trends and quality matters. Meat Sci. 2014, 98, 561-568. [CrossRef] 
31. Trokhymchuk, A.; Waldner, C.; Chaban, B.; Gow, S.; Hill, J.E. Prevalence and diversity of Campylobacter species in Saskatchewan retail ground beef. J. Food Prot. 2014, 77, 2106-2110. [CrossRef]

32. Enokimoto, M.; Kubo, M.; Bozono, Y.; Mieno, Y.; Misawa, N. Enumeration and identification of Campylobacter species in the liver and bile of slaughtered cattle. Int. J. Food Microbiol. 2007, 118, 259-263. [CrossRef]

33. Noormohamed, A.; Fakhr, M. A higher prevalence rate of Campylobacter in retail beef livers compared to other beef and pork meat cuts. Int. J. Environ. Res. Public Health 2013, 10, 2058-2068. [CrossRef]

34. Strachan, N.; MacRae, M.; Thomson, A.; Rotariu, O.; Ogden, I.; Forbes, K. Source attribution, prevalence, and enumeration of Campylobacter spp. from retail liver. Int. J. Food Microbiol. 2012, 153, 234-236. [CrossRef]

35. Ghafir, Y.; China, B.; Dierick, K.; De Zutter, L.; Daube, G. A seven-year survey of Campylobacter contamination in meat at different production stages in Belgium. Int. J. Food Microbiol. 2007, 116, 111-120. [CrossRef] [PubMed]

36. Vipham, J.L.; Brashears, M.M.; Loneragan, G.H.; Echeverry, A.; Brooks, J.C.; Chaney, W.E.; Miller, M.F. Salmonella and Campylobacter baseline in retail ground beef and whole-muscle cuts purchased during 2010 in the United States. J. Food Prot. 2012, 75, 2110-2115. [CrossRef] [PubMed]

37. Zbrun, M.V.; Olivero, C.; Romero-Scharpen, A.; Rossler, E.; Soto, L.P.; Astesana, D.M.; Blajman, J.E.; Berisvil, A.; Signorini, M.L.; Frizzo, L.S. Antimicrobial resistance in thermotolerant Campylobacter isolated from different stages of the poultry meat supply chain in Argentina. Food Control 2015, 57, 136-141. [CrossRef]

38. Bolton, D.J. Campylobacter virulence and survival factors. Food Microbiol. 2015, 48, 99-108. [CrossRef] [PubMed]

39. Jones, A.K.; Rigby, D.; Burton, M.; Millman, C.; Williams, N.J.; Jones, T.R.; Wigley, P.; O’Brien, S.J.; Cross, P.; ENIGMA Consortium. Restaurant cooking trends and increased risk for Campylobacter infection. Emerg. Infect. Dis. 2016, 22, 1208. [CrossRef]

40. Scott, M.K.; Geissler, A.; Poissant, T.; DeBess, E.; Melius, B.; Eckmann, K.; Salehi, E.; Cieslak, P.R. Notes from the field: Campylobacteriosis outbreak associated with consuming undercooked chicken liver pâte-Ohio and Oregon, December 2013-January 2014. MMWR Morb. Mortal. Wkly. Rep. 2015, 64, 399.

41. Lahti, E.; Löfdahl, M.; Ågren, J.; Hansson, I.; Olsson Engvall, E. Confirmation of a campylobacteriosis outbreak associated with chicken liver pâté using PFGE and WGS. Zoonoses Public Health 2017, 64, 14-20. [CrossRef]

42. Food Authority. Microbiological Quality of Beef, Lamb and Pork Meat Cuts and Offal. Available online: http://www.foodauthority.nsw.gov.au/_Documents/scienceandtechnical/campylobacter_in_meat_ and_offal.pdf (accessed on 10 June 2020).

43. Faten, S.H.; Amani, M.S.; Mervat, S.H.; Gaafar, M.H. Enterobacteriaceae in edible offal. J. Ben Vet Med. 2013, 25, 77-87.

44. Centers for Disease Control and Prevention. National Nosocomial Infections Surveillance (NNIS) system report, data summary from January 1992-June 2001, issued August 2001. Am. J. Infect. Control 2001, 29, 404-421. [CrossRef]

45. Shar, A.H.; Kazi, Y.F.; Kanhar, N.A.; Soomro, I.H.; Zia, S.M.; Ghumro, P.B. Drinking water quality in Rohri city, Sindh, Pakistan. Afr. J. Biotechnol. 2010, 9, 7102-7107.

46. World Health Organization. Critically Important Antimicrobials for Human Medicine-5th Revision; WHO Press: Geneva, Switzerland, 2016; ISBN 978-92-4-151222-0.

47. Thung, T.Y.; Radu, S.; Mahyudin, N.A.; Rukayadi, Y.; Zakaria, Z.; Mazlan, N.; Tan, B.H.; Lee, E.; Yeoh, S.L.; Chin, Y.Z.; et al. Prevalence, virulence genes, and antimicrobial resistance profiles of Salmonella serovars from retail beef in Selangor, Malaysia. Front Microbiol. 2018, 8, 2697. [CrossRef] [PubMed]

48. Centers for Disease Control and Prevention (CDC). Foods that Sickened People in Outbreaks with a Single Known Source, 2009-2016. Available online: https://www.cdc.gov/foodsafety/cdc-and-food-safety.html (accessed on 25 June 2020).

49. Klochko, A. Salmonella Infection (Salmonellosis) Treatment \& Management. Available online: https: //emedicine.medscape.com/article/228174-treatment (accessed on 2 May 2020).

50. Ge, B.; White, D.G.; McDermott, P.F.; Girard, W.; Zhao, S.; Hubert, S.; Meng, J. Prevalence and Antimicrobial. Appl. Environ. Microbiol. 2003, 69, 3005-3007. [CrossRef] [PubMed]

51. Carev, M.; Kovačić, A.; Novak, A.; Tonkić, M.; Jerončić, A. Campylobacter jejuni strains co-resistant to tetracycline and ciprofloxacin in patients with gastroenteritis in Croatia. Infect. Dis. 2017, 49, 268-276. [CrossRef] [PubMed] 
52. Wieczorek, K.; Osek, J. Antimicrobial resistance mechanisms among Campylobacter. Biomed. Res. Int. 2013. [CrossRef]

53. Andersen, S.R.; Saadbye, P.; Shukri, N.M.; Rosenquist, H.; Nielsen, N.L.; Boel, J. Antimicrobial resistance among Campylobacter jejuni isolated from raw poultry meat at retail level in Denmark. Int. J. Food Microbiol. 2006, 107, 250-255. [CrossRef]

54. Maćkiw, E.; Korsak, D.; Rzewuska, K.; Tomczuk, K.; Rożynek, E. Antibiotic resistance in Campylobacter jejuni and Campylobacter coli isolated from food in Poland. Food Control 2012, 23, 297-301. [CrossRef]

55. Nisar, M.; Mushtaq, M.H.; Shehzad, W.; Hussain, A.; Muhammad, J.; Nagaraja, K.V.; Goyal, S.M. Prevalence and antimicrobial resistance patterns of Campylobacter spp. isolated from retail meat in Lahore, Pakistan. Food Control 2017, 80, 327-332. [CrossRef]

56. Suzuki, H.; Yamamoto, S. Campylobacter contamination in retail poultry meats and by-products in the world: A literature survey. J. Vet. Med. Sci. 2009, 71, 255-261. [CrossRef]

57. Karczmarczyk, M.; Martins, M.; Quinn, T.; Leonard, N.; Fanning, S. Mechanisms of fluoroquinolone resistance in Escherichia coli isolates from food-producing animals. Appl. Environ. Microbiol. 2011, 77, 7113-7120. [CrossRef]

58. Little, C.; Richardson, J.; Owen, R.; De Pinna, E.; Threlfall, E. Campylobacter and Salmonella in raw red meats in the United Kingdom: Prevalence, characterization, and antimicrobial resistance pattern, 2003-2005. Food Microbiol. 2008, 25, 538-543. [CrossRef]

59. Ohtsuka, K.; Tanaka, M.; Ohtsuka, T.; Takatori, K.; Hara-Kudo, Y. Comparison of detection methods for Escherichia coli $\mathrm{O} 157$ in beef livers and carcasses. Foodborne Pathog. Dis. 2010, 7, 1563-1567. [CrossRef]

60. Chantziaras, I.; Boyen, F.; Callens, B.; Dewulf, J. Correlation between veterinary antimicrobial use and antimicrobial resistance in food-producing animals: A report on seven countries. J. Antimicrob. Chemother. 2014, 69, 827-834. [CrossRef]

61. Aslam, M.; Diarra, M.S.; Checkley, S.; Bohaychuk, V.; Masson, L. Characterization of antimicrobial resistance and virulence genes in Enterococcus spp. isolated from retail meats in Alberta, Canada. Int. J. Food Microbiol. 2012, 156, 222-230. [CrossRef]

62. Klare, I.; Konstabel, C.; Badstübner, D.; Werner, G.; Witte, W. Occurrence and spread of antibiotic resistances in Enterococcus faecium. Int. J. Food Microbiol. 2003, 88, 269-290. [CrossRef]

63. Jackson, C.R.; Fedorka-Cray, P.J.; Barrett, J.B.; Hiott, L.M.; Woodley, T.A. Prevalence of streptogramin resistance in enterococci from animals: Identification of vatD from animal sources in the USA. Int. J. Antimicrob. 2007, 30, 60-66. [CrossRef]

64. Carvalho, I.; del Campo, R.; Sousa, M.; Silva, N.; Carrola, J.; Marinho, C.; Santos, T.; Carvalho, S.; Nóvoa, M.; Quaresma, M.; et al. Antimicrobial-resistant Escherichia coli and Enterococcus spp. isolated from Miranda donkey (Equus asinus): An old problem from a new source with a different approach. J. Med. Microbiol. 2017, 66, 191-202. [CrossRef]

65. Arias, C.A.; Murray, B.E. The rise of the Enterococcus: Beyond vancomycin resistance. Nat. Rev. Microbiol. 2012, 10, 266. [CrossRef]

66. Nguyen, D.T.A.; Kanki, M.; Do Nguyen, P.; Le, H.T.; Ngo, P.T.; Tran, D.N.M.; Le, N.H.; Van Dang, C.; Kawai, T.; Kawahara, R.; et al. Prevalence, antibiotic resistance, and extended-spectrum and AmpC $\beta$-lactamase productivity of Salmonella isolates from raw meat and seafood samples in Ho Chi Minh City, Vietnam. Int. J. Food Microbiol. 2016, 236, 115-122. [CrossRef]

67. Chatre, P.; Haenni, M.; Meunier, D.; Botrel, M.-A.; Calavas, D.; Madec, J.-Y. Prevalence and antimicrobial resistance of Campylobacter jejuni and Campylobacter coli isolated from cattle between 2002 and 2006 in France. J. Food Prot. 2010, 73, 825-831. [CrossRef]

68. Ramírez-Castillo, F.Y.; Moreno-Flores, A.C.; Avelar-González, F.J.; Márquez-Díaz, F.; Harel, J.; Guerrero-Barrera, A.L. An evaluation of multidrug-resistant Escherichia coli isolates in urinary tract infections from Aguascalientes, Mexico: Cross-sectional study. Ann. Clin. Microbiol. Antimicrob. 2018, 17, $34-35$. [CrossRef]

69. Weiner, L.M.; Webb, A.K.; Limbago, B.; Dudeck, M.A.; Patel, J.; Kallen, A.J.; Edwards, J.R.; Sievert, D.M. Antimicrobial-Resistant Pathogens Associated with Healthcare-Associated Infections: Summary of Data Reported to the National Healthcare Safety Network at the Centers for Disease Control and Prevention, 2011-2014. Infect. Dis. Contrl. Hosp. Epidemiol. 2016, 37, 1288-1301. [CrossRef] 
70. Whichard, J.M.; Medalla, F.; Hoekstra, R.M.; Mcdermott, P.F.; Joyce, K.; Chiller, T.; Barrett, T.J.; White, D.G. Evaluation of antimicrobial resistance phenotypes for predicting multidrug-resistant Salmonella recovered from retail meats and humans in the United States. J. Food Prot. 2010, 73, 445-451. [CrossRef]

71. Eyý, A.; Arslan, S. Prevalence of Escherichia coli in retail poultry meat, ground beef, and beef. Med. Weter 2012, 68, 238.

72. World Health Organization (WHO). Critically Important Antimicrobials for Human Medicine, 5th ed.; WHO Advisory Group on Integrated Surveillance of Antimicrobial Resistance (AGISAR); WHO Press: Geneva, Switzerland, 2016; ISBN 978-92-4-151222. 